\title{
EFFECTS OF RATION SIZE AND TEMPERATURE ON MOULT INCREMENT AND METABOLIC PARAMETERS OF JUVENILE NOBLE CRAYFISH, ASTACUS ASTACUS
}

\author{
B. RENAI (1), F. GHERARDI (1) AND E. D'AGARO (2)
}

(1) Dipartimento di Biologia Animale e Genetica "Leo Pardi", University of Florence, Via Romana 17, 50125 Florence, Italy. (E-mail correspondence: barbara.renai@unifi.it; E-Mail: gherardi@DBAG.UNIFI.IT)

(2) Dipartimento di Scienze Animali, University of Udine, Via S. Mauro 2, 33010 Pagnacco (UD), Italy (E-Mail: dagaro@dspa.uniud.it)

Reçu le 4 septembre 2006

Accepté le 18 septembre 2007

Received September 4, 2006

Accepted September 18, 2007

\section{ABSTRACT}

A laboratory experiment was carried out to test the combined effects of ration size ( 1 vs $3 \%$ body weight, b.w.) and temperature $\left(15 \pm 2\right.$ vs $22 \pm 2{ }^{\circ} \mathrm{C}$ ) on moult increment and metabolic parameters of 80 juvenile noble crayfish (Astacus astacus). The maximum daily consumption (Cmax) and respiration rate $(\mathrm{R})$ were used to calculate the growth scope (i.e. the difference between maximum daily energy consumption and energy costs at a given temperature). The conversion of $\mathrm{R}$ into a food-equivalent unit allowed the comparison with Cmax. Results showed that crayfish obtained the maximum moult increment when fed $3 \%$ b.w. while temperature seemed to play a less relevant role on growth rate per moult, affecting only the moulting frequency. Crayfish $A$. astacus fed ad libitum showed a relative insensitivity to the metabolic parameters (oxygen uptake, $\mathrm{R}$ and $\mathrm{Cmax}$ ) within the analysed range of temperatures, possibly as a reflection of this "species" distribution across a broad variety of habitats with different thermal regimes. In the present study, A. astacus displayed characteristics proper of a K-selected species, as slow to moderate growth.

Key-words: Astacus astacus, moult increment, temperature, ration size, maximum daily consumption, oxygen uptake, respiration rate.

\section{EFFETS DE LA RATION ALIMENTAIRE ET DE LA TEMPÉRATURE SUR L'AUGMENTATION DE LA MUE ET SUR LES PARAMĖTRES MÉTABOLIQUES DE LA JEUNE ÉCREVISSE NOBLE, ASTACUS ASTACUS.}

\section{RÉSUMÉ}

Une expérience de laboratoire a été conduite pour tester les effets combinés de la ration alimentaire ( 1 vs $3 \%$ du poids du corps (b.w.)) et de la température (15 \pm 2 vs 22 $\pm 2{ }^{\circ} \mathrm{C}$ ), sur l'augmentation de la mue et des paramètres métaboliques de 80 juvéniles d'écrevisse noble (Astacus astacus). La consommation maximum journalière (Cmax) et le taux de respiration $(\mathrm{R})$ ont été utilisés pour calculer un paramètre qualifiant la croissance (la différence entre la consommation maximum journalière d'énergie et les coûts énergétiques à une température donnée). La conversion de $\mathrm{R}$ en unités d'alimentation équivalent a permis la confrontation avec Cmax. Les résultats ont montré que les écrevisses avaient 
l'augmentation maximum de mue quand leur ration alimentaire correspondait à $3 \%$ de leur poids corporel, tandis que la température semblait jouer un rôle moins élevé sur le taux de croissance de la mue, influençant seulement la fréquence des mues. Les écrevisses alimentées ad libitum ont montré une relative insensibilité aux paramètres métaboliques (demande d'oxygène, $\mathrm{R}$ et $\mathrm{Cmax}$ ) dans l'intervalle de température analysée, sans doute en relation avec la distribution de cette espèce, dans une grande variété d'habitats avec différents régimes thermiques. Dans cet étude, $A$. astacus a montré des caractéristiques typiques d'une espèce K-sélectionnée, avec une croissance lente à modérée.

Mots-clés: Astacus astacus, augmentation de la mue, température, quantité de la ration, consommation maximum journalière, demande d'oxygène, taux de respiration.

\section{INTRODUCTION}

Crayfish are a prominent component of many aquatic ecosystems. Despite of their importance as key species, knowledge of ecological requirements for most crayfish species is fragmentary or lacking (TAYLOR et al., 1996), and only few bioenergetic studies have included crayfish (MOMOT, 1995). Together with fecundity (COREY, 1987; MUCK, 1995), growth rate is obviously one of the principal factors in population dynamics: large size is a prerequisite for crayfish to acquire and maintain a shelter (RABENI, 1985) and to avoid predation. In particular, a better knowledge of growth rate at diverse food availabilities (ABRAHAMSSON, 1971) and at different temperatures seems essential for the conservation of indigenous crayfish species facing threats from both introduced species (PAGLIANTI et al., 2004) and altered thermal habitats (WHITLEDGE and RABENI, 2003).

The relationship between water temperature and growth rate was previously analysed in some Australian (MILLS, 1989; MORRISSY, 1990; SMALLRIDGE and GEDDES, 1991; VILLAREAL, 1991; ROUSE and KARTAMULIA, 1992; KING, 1994; AUSTIN, 1995; JONES and ROMAIRE, 1995) and North American crayfish species as: Orconectes rusticus (cf. MUNDAHL and BENTON, 1990), O. virilis (cf. MOMOT, 1984; WETZEL and BROWN, 1993), O. immunis (cf. WETZEL and BROWN, 1993) and Pacifastacus leniusculus (WESTMAN, 1973). However, only few studies (VERHOEF et al., 1998; PAGLIANTI and GHERARDI, 2004) considered the effects of temperature on the separate components of growth. The life cycle of crayfish progresses in fact through a series of moults interspersed by intermoults during which the animals increase in size. Growth is therefore a function of both length increment per moult and the number of moults completed per unit time. Consequently, in addition to measuring changes in wet weight and cephalothorax length over time (GEDDES et al., 1988; ACKEFORS et al., 1995; JONES et al., 1996), growth rate should be analysed in terms of the frequency of moults and the increase in size after a given moult (moult increment) (HARTNOLL, 1982).

The maximum daily consumption and the respiration rate are measured to obtain the growth scope. This represents the difference between maximum daily energy consumption and energy costs at a given temperature, being the amount of absorbed energy potentially available for growth at that temperature (WARREN and DAVIS, 1967; JOBLING, 1997; ZWEIFEL et al., 1999). A high growth scope, as the growth rate, would represent an important advantage among crayfish being size positively related to fecundity (COREY, 1987; MUCK, 1995), shelter acquisition (RABENI, 1985) and predation, because fishes often prey selectively on smaller crayfish (PROBST et al., 1984; GARVEY et al., 1994). Maximum daily consumption and respiration rate are two components of the Wisconsin fish bioenergetics models (HEWETT and JOHNSON, 1992), which identify the relationship between growth scope of a species and temperature. The Wisconsin fish bioenergetics models have been already used with invertebrates, e.g. mysids (RUDSTAM, 1989) and crayfish (WHITLEDGE and RABENI, 2003). 
The work aimed at testing the combined effects of feeding rate and temperature on growth rate and metabolic parameters of Astacus astacus juveniles cultured in a battery system with recirculating water. The results of this study can be used to develop growth models for the juveniles of this species in order to summarise overall growth performance and to optimise culture conditions. Furthermore, the identification of the nutritional and environmental conditions, that maximise energy utilisation by crayfish (VILLAREAL, 1991), will benefit production in commercial ponds. In fact the noble crayfish (Astacus astacus) is the only indigenous species cultured to a large extent in several European countries and the juveniles are extensively cultured for restocking purposes (HOLDICH, 1993). Astacus astacus has been exploited for centuries due to its world-wide recognition as being a culinary delicacy (SPITZY, 1973; BRINCK, 1975; HOLDICH and LOWERY, 1988; WESTMAN et al., 1990). This species naturally occurs in at least 20 European countries ranging from Italy and Greece in the south to the Scandinavian peninsula and Finland in the north, and from France in the west to Russia in the east.

\section{MATERIAL AND METHODS}

\section{Moult increment and growth regression model}

Astacus astacus juveniles (0+) were obtained from the First Bavarian Crayfish Hatchery at Augsburg (Germany) and were grown from May to July 2002 under laboratory conditions at a natural L/D photoperiod. Eighty crayfish (initial mean weight: $0.42 \pm$ $0.02 \mathrm{~g}$ and mean cephalotorax length: $12.78 \pm 0.14 \mathrm{~mm}$ ) were randomly allotted into 4 rectangular plexiglas aquaria $(40 \times 40 \times 20 \mathrm{~cm})$, each containing 25 litres of dechlorinated tap water. Water-recirculation was maintained by a pump at $60 \mathrm{I} \cdot \mathrm{min}^{-1}$ provided with a filter allowing catabolita filtering and water oxygenation. Submersed heaters (25W), controlled by a thermostat or coolers (Teco RA 200), were used to maintain water temperature at the constant $\left( \pm 1^{\circ} \mathrm{C}\right)$ desired value. Crayfish (20 juveniles per aquarium) were reared for 70 days at two different temperatures $\left(15 \pm 2\right.$ and $\left.22 \pm 2{ }^{\circ} \mathrm{C}\right)$ and fed either 1 or $3 \%$ of the total body weight (b.w.) with a formulated feed. Proximate analysis was performed following the methods of AOAC (1990) and gross energy by an adiabatic calorimeter. The experimental diet was made of $40.95 \%$ DM of crude protein, $7.42 \%$ DM of lipid and $1.24 \%$ DM of crude fibre.

Following the experimental protocol of PAGLIANTI et al. (2004), juveniles were held individually in glass canning jars of $8 \mathrm{~cm}^{2}$ in order to prevent cannibalism and fights and to provide a given amount of food to each crayfish. Twenty jars were submerged in a horizontal position in adjacent four aquaria and were closed with a net (mesh size: $2 \mathrm{~mm}$ ) to allow water circulation. This system allowed us to follow the individual growth of each specimen under the same rearing conditions (i.e. food quantity, temperature, and water quality). Animals were acclimated to feeding regimes and temperatures for one week prior to testing.

Twice a week the water in each jar and in each aquarium was totally siphoned out and replaced, taking care to remove any uneaten food, shed exoskeleton, and dead animals, and the prescribed quantity of nutrients was weighed and put in every jar. Once a week, crayfish were carefully blotted with paper towel to remove excess moisture and then weighed (to the nearest $0.001 \mathrm{~g}$ ) and measured for their cephalothorax length $(\mathrm{Cl})$ (accurate to $0.1 \mathrm{~mm}$ ). Moulting was determined by the presence of shed exoskeletons or part thereof within the culture jars.

Moult increment (Mi), in terms of wet weight and $\mathrm{Cl}$, was defined as:

(1) $\mathrm{Mi}_{\mathrm{w}}(\%)=\mathrm{N}_{\mathrm{m}}^{-1} \cdot 100 \sum_{\mathrm{i}=1}^{\mathrm{Nm}}\left(\mathrm{W}_{t}-\mathrm{W}_{0}\right)_{i} \cdot\left(\mathrm{W}_{t}^{-1}\right)_{i}$ 
where $W_{t}$ and $W_{0}$ were respectively the final and initial wet weights (mg) for each moult and $\mathrm{N}_{\mathrm{m}}$ was the number of moults for each juvenile; and

(2) $\mathrm{Mi}_{w}(\%)=\mathrm{N}_{\mathrm{m}}^{-1} \cdot 100 \sum_{\mathrm{i}=1}^{\mathrm{Nm}}\left(\mathrm{Cl}_{t}-\mathrm{Cl}_{0}\right)_{i} \cdot\left(\mathrm{Cl}_{t}^{-1}\right)_{i}$

where $\mathrm{Cl}_{\mathrm{t}}$ and $\mathrm{Cl}_{0}$ were respectively the final and initial $\mathrm{Cl}(\mathrm{mm})$ for each moult and $\mathrm{N}_{\mathrm{m}}$ was the number of moults for each juvenile.

Besides, we represented the $\log _{10}$ of weight against the time as recommended by HARTNOLL (1982) and HOPKINS (1992).

\section{Standard aerobic metabolism}

At the end of the growth trial, ten juveniles were randomly selected from the group of animals fed $3 \%$ b.w. This feeding rate can be considered as the ad libitum level, since part of the ration remained always uneaten into the experimental jars.

Oxygen uptake rates were determined at the two temperatures $\left(15 \pm 2\right.$ vs $22 \pm 2{ }^{\circ} \mathrm{C}$ using 5 crayfish per treatment), under a natural L/D photoperiod, using the respirometer method with a dual-chamber open system (LAMPERT, 1986). The instrument was composed of a respirometric chamber with one animal and a chamber without crayfish used as a control. The scheme of flow-through respirometer used in this trial was the same described in PAGLIANTI et al. (2004). Every 15 minutes, the water coming from the chambers can be directed to two alternate electrodes (LAMPERT, 1986).

Before the experiment started, each crayfish was starved for one day $(\mathrm{CECH}, 1990)$ and was housed in a cylinder of net that was inserted into the respirometer chamber to avoid any movement. This method allowed us to obtain the rate of oxygen uptake and therefore provided an estimation of energy expenditure for maintenance standard metabolism, i.e. the metabolism at minimum activity level (FRY, 1957). Juveniles were acclimatised to the experimental condition for 45 minutes. Each experimental session lasted 90 minutes.

Oxygen uptake (Ou) (LAMPERT, 1986) and Respiration rate $(\mathrm{R})$ at each temperature were calculated as follows:

(1) Ou $\left(\mathrm{mg} \mathrm{O}_{2} \cdot \mathrm{h}^{-1}\right)=(\mathrm{D} \cdot \mathrm{S} \cdot \mathrm{F})$

where $\mathrm{D}$ was the dissolved oxygen uptake estimated as the difference between the average value measured in the control chamber, in each 15 minutes interval, and the average value revealed, by the same probe, in the experimental chamber during previous and successive intervals; $\mathrm{S}$ was the solubility of oxygen in water in equilibrium with air at $760 \mathrm{~mm} \mathrm{Hg}$ pressure and $100 \%$ relative humidity $\left(10.07 \mathrm{mg} \mathrm{O} \cdot \cdot^{-1}\right.$ at $15^{\circ} \mathrm{C}$ and $8.74 \mathrm{mg}$ $\mathrm{O}_{2} \cdot \mathrm{l}^{-1}$ at $\left.22{ }^{\circ} \mathrm{C}\right)$ and $\mathrm{F}$ was the water flow $\left(810 \mathrm{ml} \cdot \mathrm{h}^{-1}\right)$ in both experimental and control chambers. Oxygen uptake rate was calculated comparing measurements obtained with the same electrode in different times (with or without juveniles), rather than with different probes at the same time, to avoid the inclusion in the analysis of differences simply due to the probes (PAGLIANTI et al., 2004);

(2) $\mathrm{R}\left(\mathrm{g} \mathrm{O}_{2} \cdot \mathrm{g}^{-1} \mathrm{~d}^{-1}\right)=\left(\mathrm{Ou} \cdot \mathrm{W}_{\mathrm{a}}^{-1}\right) \mathrm{d}$

where $\mathrm{Ou}$ was the Oxygen uptake rate, $\mathrm{W}_{\mathrm{a}}$ was the $A$. astacus weight and $\mathrm{d}$ indicated 24 hours.

Respiration rate was converted to Joule-equivalent unit using a multiplier of 13.724 $\mathrm{J} \cdot \mathrm{g} \mathrm{O}_{2}^{-1}$ (ADAMS and BRECK, 1990) and than into feed-equivalent units ( $\mathrm{g} \mathrm{feed} \cdot \mathrm{g}^{-1} \cdot \mathrm{d}^{-1}$ ) by dividing by the energy density of nutrients $\left(19181.58 \mathrm{~J} \cdot \mathrm{g}^{-1}\right)$. This conversion into feedequivalent units $\left(\mathrm{g}\right.$ feed $\cdot \mathrm{g}^{-1} \cdot \mathrm{d}^{-1}$ ) allowed us to compare directly between $\mathrm{R}$ rate data and maximum daily consumption (Cmax) data. 


\section{Maximum daily consumption}

At the end of the growth experiment, we measured the Cmax rates of 10 juveniles fed $3 \%$ b.w. and reared at $15 \pm 2$ and $22 \pm 2{ }^{\circ} \mathrm{C}$ (five per treatment). The weight of feed consumed was estimated in terms of dry weight at $60^{\circ} \mathrm{C}$ (24 hours) as:

Cmax $\left(g \cdot g^{-1} d^{-1}\right)=\left(W_{s}-W_{r}\right) \cdot W_{a}^{-1}$

where $\mathrm{W}_{\mathrm{s}}, \mathrm{W}_{\mathrm{r}}$ and $\mathrm{W}_{\mathrm{a}}$ were respectively the dry weights of supplied (24 h earlier) and recovered feed and body weight of crayfish.

Weight of supplied feed $\left(\mathrm{W}_{\mathrm{s}}\right)$ value was calculated considering feed losses (for leaching and disintegration) due to the flowing water into the jars. In order to determine the quantity of nutrient loss, 20 jars filled only with a fixed quantity of feed, ranging from $0.009 \mathrm{~g}$ to $0.036 \mathrm{~g}$, were inserted into the aquaria (10 per aquarium) at the same time.

Weight of supplied feed was computed from the linear equation $y=a x+c$ representing the nutrient dissipation into the water, where $x$ was the dry weight of supplied feed $24 \mathrm{~h}$ earlier and $\mathrm{y}$ was $\mathrm{W}_{\mathrm{s}}$ considering feed losses.

Nitrite, nitrate, ammonium, and phosphate concentrations were measured using Aquamerck $($ Darmstadt, Germany) reagent kits.

\section{STATISTICAL ANALYSES}

Moult increments were analysed using two-way ANOVAS, while one-way ANOVA were used to test the significance of differences for each treatment. We analysed frequency data by G-test. $\log _{10}$ transformed weight and $\mathrm{Cl}$ data were combined to produce a $\mathrm{Cl}$ weight, a weight-Cmax and a weight- $R$ relationship and a growth model of weight vs time and $\mathrm{Cl}$ vs time for each temperature and nutrient ration, using regression analysis (Pearson correlation coefficient). Regression coefficients (slopes) were compared using analysis of covariance (ANCOVA) with pairwise comparisons of slopes after Bonferroni corrections to reduce Type I errors (ZAR, 1990). $P$ values of less than 0.05 were considered statistically significant.

\section{RESULTS}

\section{Survival and growth regression model}

Juvenile survival, ranging from 65 to $95 \%$, was not affected by the ration size $(G=1.856, d f=1, P>0.1)$ and by the temperature $(G=0.015, d f=1, P>0.1)$.

Individuals fed $3 \%$ b.w. at $22{ }^{\circ} \mathrm{C}$ showed a significantly higher increase of body weight $(\mathrm{F}=56.472, \mathrm{df}=1 \& 63, \mathrm{P}<0.001)$ (final weights: $1 \%$ b.w. \& $15^{\circ} \mathrm{C}, 0.588 \pm 0.02 \mathrm{~g} ; 3 \%$ b.w. \& $15{ }^{\circ} \mathrm{C}, 0.756 \pm 0.03$ g; $1 \%$ b.w. $\& 22{ }^{\circ} \mathrm{C}, 0.630 \pm 0.02$ g; $3 \%$ b.w. \& $22{ }^{\circ} \mathrm{C}, 0.840 \pm 0.05$ g).

The linear regression model of $\log _{10}$ weight $(\mathrm{mg})$ and $\log _{10} \mathrm{Cl}(\mathrm{mm})$ vs time showed a significant correlation only in the juveniles fed $3 \%$ b.w. $\left(\log _{10}\right.$ weight at $15{ }^{\circ} \mathrm{C}, r=0.208$, $\mathrm{df}=208, \mathrm{P}<0.01$; $\log _{10}$ weight at $22{ }^{\circ} \mathrm{C}: \mathrm{r}=0.317$, $\mathrm{df}=208, \mathrm{P}<0.001$; $\log _{10} \mathrm{Cl}$ at $15^{\circ} \mathrm{C}$ : $r=0.235, d f=208, P<0.001 ; \log _{10} C l$ at $\left.22{ }^{\circ} \mathrm{C}: r=0.356, d f=208, P<0.001\right)$.

The ANCOVA analysis did not show any difference between regression coefficients (slopes) calculated on juveniles fed $3 \%$ b.w. (weight: $t=0.360, d f=414, P>0.05$; $C l: t=1.740$, $\mathrm{df}=414, \mathrm{P}>0.05$ ), suggesting that the temperature does not influence the overall growth rate. 


\section{Moult increment and length-weight relationship}

A raise in the temperature did not exert any influence on the growth rate per moult (weight: $\mathrm{F}=0.154, \mathrm{df}=1 \& 55, \mathrm{P}>0.1 ; \mathrm{Cl}: \mathrm{F}=0.042, \mathrm{df}=1 \& 55, \mathrm{P}>0.1$ ). The maximum moult increment of both body weight (\%) and $\mathrm{Cl}(\%)$ was obtained when juveniles were fed $3 \%$ b.w. (weight: $\mathrm{F}=29.070, \mathrm{df}=1 \& 55, \mathrm{P}<0.0001 ; \mathrm{Cl}: \mathrm{F}=15.558, \mathrm{df}=1 \& 55, \mathrm{P}<0.001$ ). No significant interaction was found between temperature and ration size (weight: $F=0.006$, $\mathrm{df}=1 \& 55, \mathrm{P}>0.1 ; \mathrm{Cl}: \mathrm{F}=0.479, \mathrm{df}=1 \& 55, \mathrm{P}>0.1)$ (Figure 1A,B).

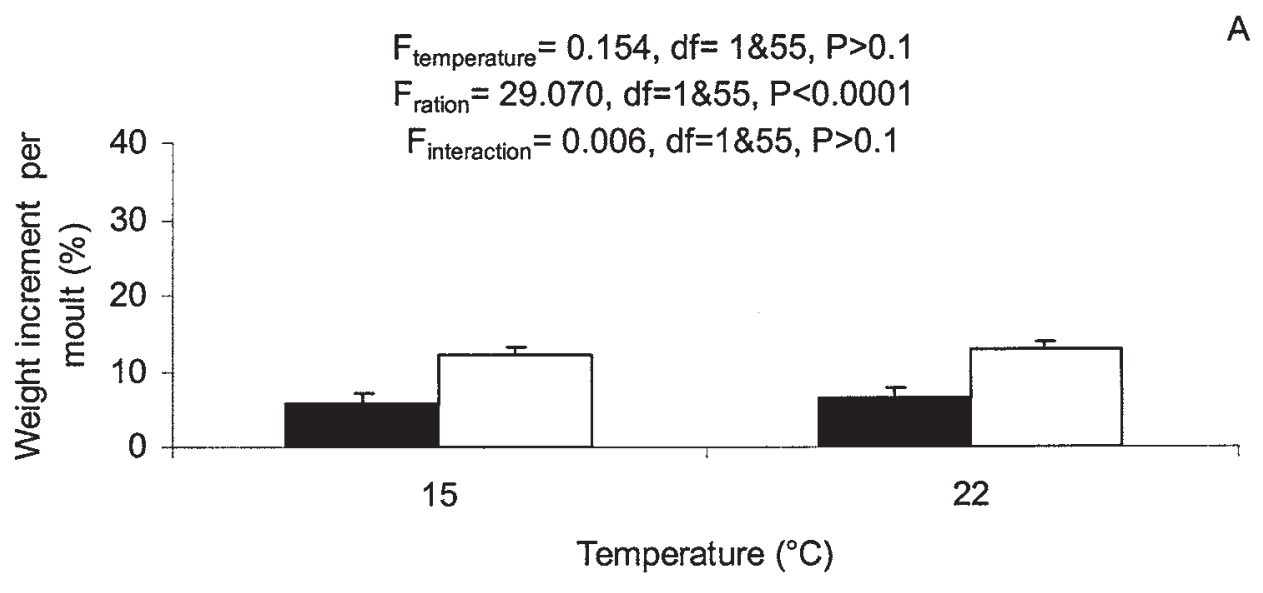

$1 \%$ b.w. $n=20 \square 3 \%$ b.w. $n=37$

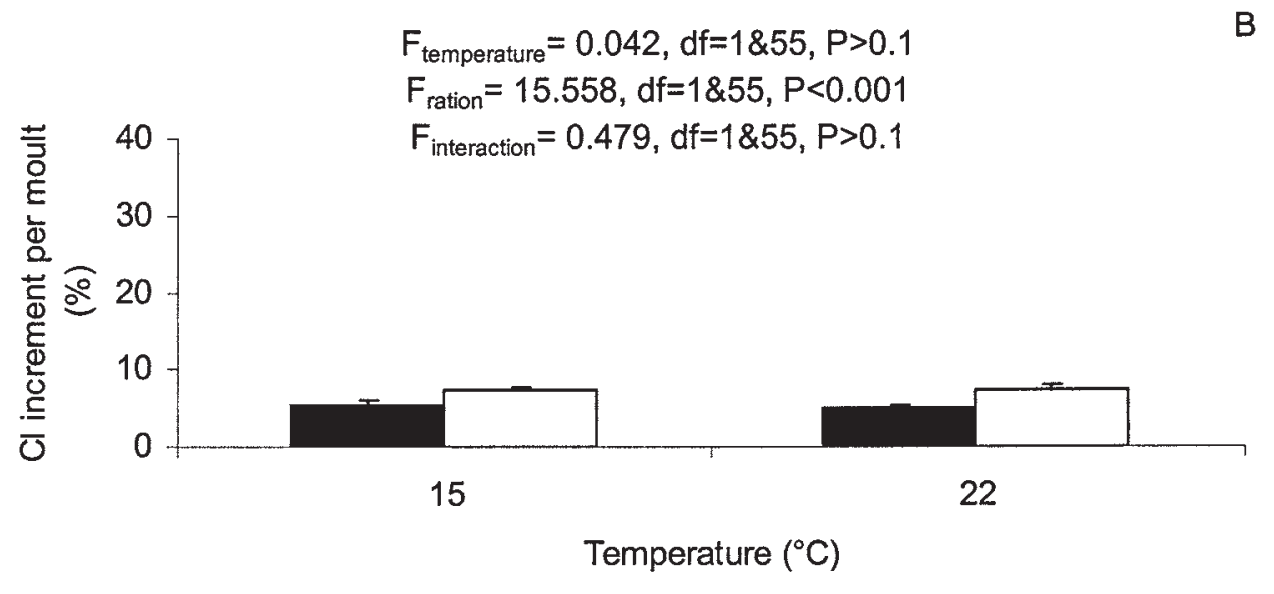

$1 \%$ b.w. $n=20 \square 3 \%$ b.w. $n=37$

\section{Figure 1}

Weight (A) and cephalothorax length (CI) (B) increment (in \%) per moult (mean and SE) of $A$. astacus juveniles.

\section{Figure 1}

Augmentation du poids (A) et de la longueur du cephalothorax (CI) (B) (en \%) par mue (valeur moyenne et SE) des A. Astacus juvéniles. 
$\log _{10}$ mean weight $(\mathrm{mg})$ and $\log _{10}$ mean $\mathrm{Cl}(\mathrm{mm})$ were used to calculate a Cl-weight relationship for each treatment $\left(1 \%\right.$ : at $15{ }^{\circ} \mathrm{C}, \mathrm{r}=0.972$, df $=12, \mathrm{P}<0.01$; at $22{ }^{\circ} \mathrm{C}, \mathrm{r}=0.993$, $\mathrm{df}=11, \mathrm{P}<0.01 ; 3 \%$ : at $15^{\circ} \mathrm{C}, \mathrm{r}=0.983, \mathrm{df}=17, \mathrm{P}<0.01$; at $22^{\circ} \mathrm{C}, \mathrm{r}=0.972, \mathrm{df}=17, \mathrm{P}<0.01$ ). The $\mathrm{Cl}$-weight relationship fitted exponential growth function (Figure 2). ANCOVA did not show significant differences between regression coefficients calculated for each treatment (i.e. slopes) (1\%: $t=0.150, d f=23, P>0.05 ; 3 \%: t=0.499, d f=34, P>0.05 ; 15{ }^{\circ} \mathrm{C}: t=0.514$, $\left.\mathrm{df}=29, \mathrm{P}>0.05 ; 22{ }^{\circ} \mathrm{C}: \mathrm{t}=1.274, \mathrm{df}=28, \mathrm{P}>0.05\right)$.

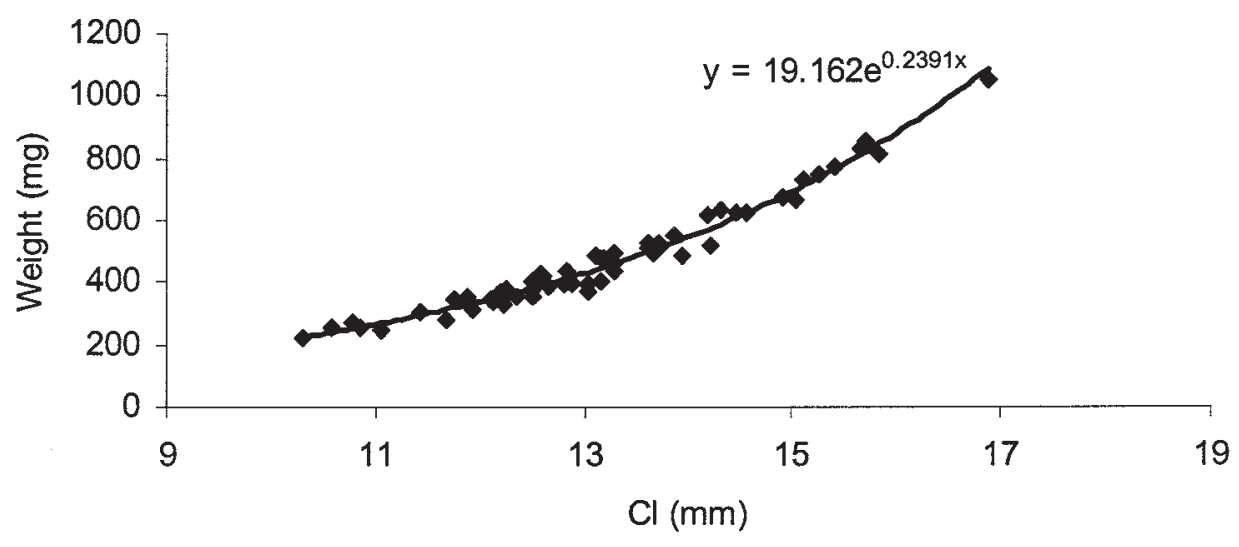

Figure 2

Relationship between cephalothorax length $(\mathrm{Cl})$ and weight of $A$. astacus juveniles surviving until the end of the growth experiment. Data of all rearing conditions were pooled because the relationship did not vary among temperature-ration size combinations.

Figure 2

Relation entre la longueur du cephalothorax (Cl) et le poids des A. Astacus juvéniles survivant jusqu'à la fin des expérimentations de croissance. Les données relatives aux conditions d'élevage sont agglomérées parce que la relation ne variait pas en fonction des combinaisons température-taille de ration.

\section{Number of moults}

The number of moults per individual, ranging from 1 to 3 , was greater in juveniles reared at $22{ }^{\circ} \mathrm{C}$ than at $15^{\circ} \mathrm{C}(\mathrm{F}=4.220, \mathrm{df}=1 \& 63, \mathrm{P}<0.05)$ and fed $3 \%$ b.w. than $1 \%$ b.w. $(\mathrm{F}=20.911, \mathrm{df}=1 \& 63, \mathrm{P}<0.0001)$. Moreover, we recorded a significant interaction between temperature and feeding rate $(\mathrm{F}=4.449, \mathrm{df}=1 \& 63, \mathrm{P}<0.05)$ (Figure 3$)$. A higher number of moults was found at $22{ }^{\circ} \mathrm{C}$ and $3 \%$ b.w. $(\mathrm{t}=3.404, \mathrm{df}=36, \mathrm{P}<0.01)$. No difference was found in crayfish fed $1 \%$ b.w. reared at different temperatures $(t=0.092, d f=25, P>0.1)$. The duration of the intermoult period was not analysed due to the small number of moults (see Figure 3).

\section{Respiration and maximum daily consumption}

Aerobic metabolism of juveniles fed $3 \%$ b.w. was not influenced by different temperatures $(t=0.368, d f=8, P>0.1)$ (Figure 4). $R$ ranged from $0.006 \mathrm{~g} \mathrm{O}_{2} \cdot \mathrm{g}^{-1} \cdot \mathrm{d}^{-1}$ to $0.023 \mathrm{~g}$ $\mathrm{O}_{2} \cdot \mathrm{g}^{-1} \cdot \mathrm{d}^{-1}$ with a mean value of $0.013 \mathrm{~g} \mathrm{O}_{2} \cdot \mathrm{g}^{-1} \cdot \mathrm{d}^{-1}$. Body weights were negatively correlated to respiration rates in juveniles reared at $22{ }^{\circ} \mathrm{C}\left(\log _{10}\right.$ weight $v s \log _{10} R: r=-0.978, d f=8$, $\mathrm{P}<0.01)$. 


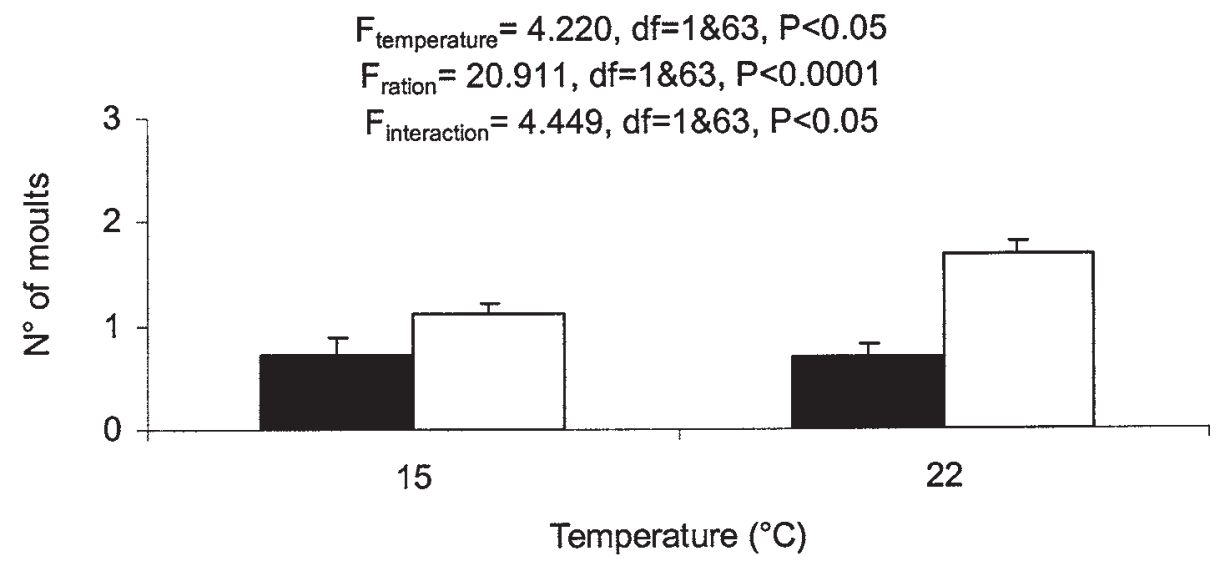

- $1 \%$ b.w. $n=27 \square 3 \%$ b.w. $n=38$

\section{Figure 3}

Number of moults (mean and SE) during the growth experiment for $A$. astacus juveniles.

\section{Figure 3}

Nombre de mues (valeur moyenne et SE) durant l'expérimentation de croissance pour les $A$. astacus juvéniles.

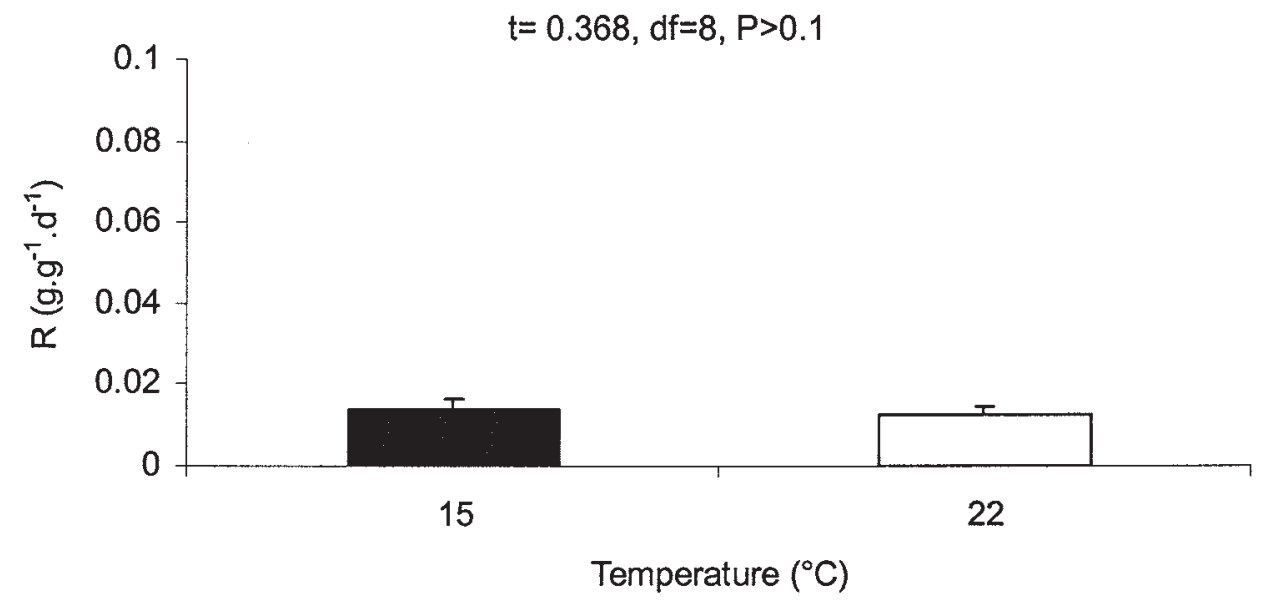

Figure 4

Respiration rates (mean and SE) of $A$. astacus juveniles fed $3 \%$ b.w..

\section{Figure 4}

Taux de respiration (moyenne et SE) des A. Astacus juvéniles alimentés avec $3 \%$ b.w..

Maximum daily Consumption (Cmax) ranging from $0.0024 \mathrm{~g} \cdot \mathrm{g}^{-1} \cdot \mathrm{d}^{-1}$ to 0.0133 $\mathrm{g} \cdot \mathrm{g}^{-1} \cdot \mathrm{d}^{-1}$ with a mean value of $0.0085 \mathrm{~g} \cdot \mathrm{g}^{-1} \cdot \mathrm{d}^{-1}$, did not change with temperature $(\mathrm{t}=-0.768$, $\mathrm{df}=8, \mathrm{P}>0.1$ ) (Figure 5). No correlation was found between weight and Cmax at the two temperatures $\left(\log _{10}\right.$ weight vs $\log _{10} \mathrm{Cmax}, 15^{\circ} \mathrm{C}: \mathrm{r}=-0.588 \mathrm{df}=8, \mathrm{P}>0.1 ; 22{ }^{\circ} \mathrm{C}: \mathrm{r}=0.548$, $d f=8, P>0.1)$. Growth scope $(C \max -R)$ was not influenced by temperature $(t=-0.770, d f=8$, $P>0.1$ ) (Figure 6). 


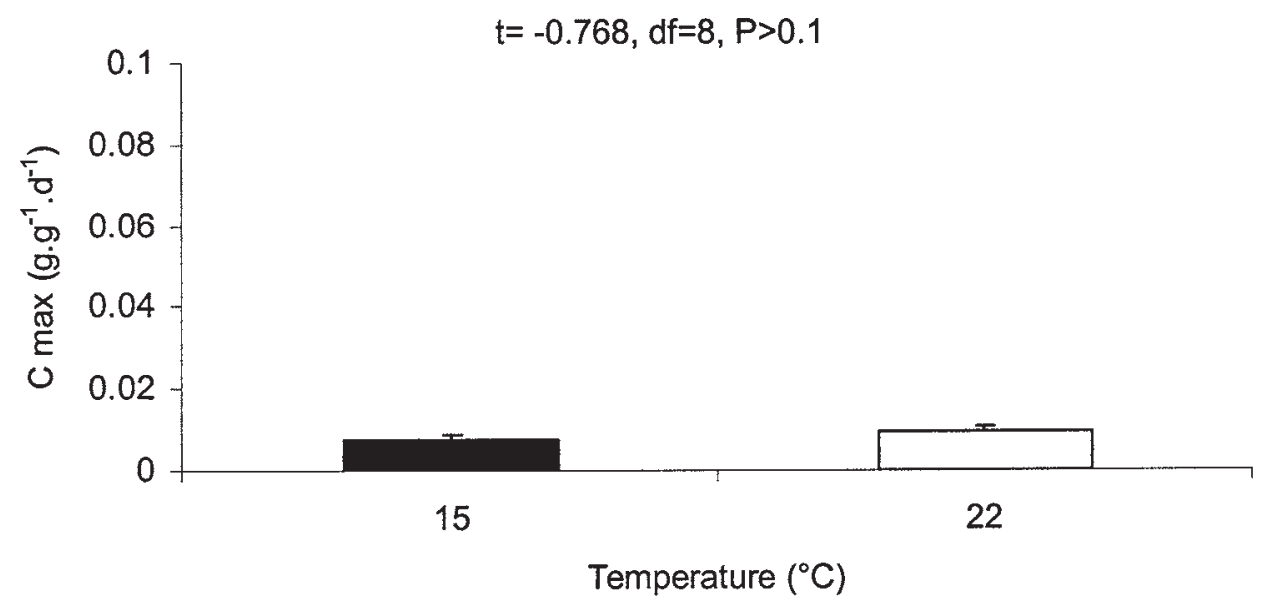

Figure 5

Maximum daily consumption (mean and SE) of $A$. astacus juveniles fed $3 \%$ b.w..

Figure 5

Consommation maximum journalière (moyenne et SE) des A. Astacus juvéniles alimentés avec $3 \%$ b.w..

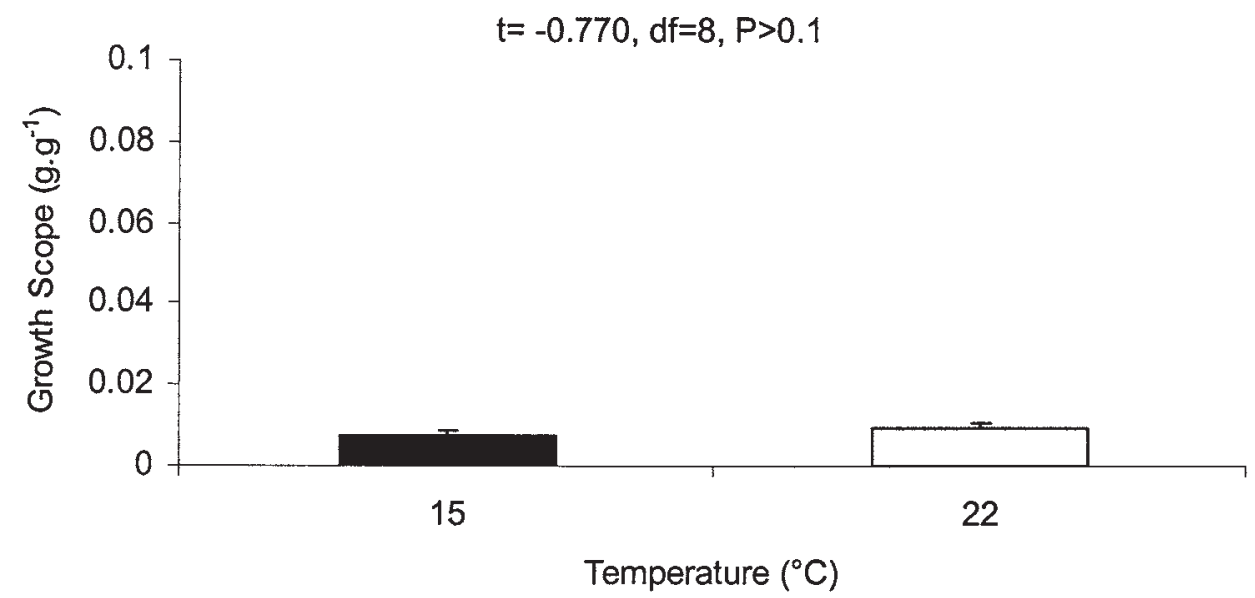

Figure 6

Growth scope (maximum daily consumption - respiration rate) (mean and SE) of A. astacus juveniles fed $3 \%$ b.w..

Figure 6

Extension de la croissance (consommation maximum journalière - taux de respiration) (moyenne et SE) des $A$. Astacus juvéniles alimentés avec 3\% b.w..

At the end of the experiment, nitrite, nitrate, ammonium, and phosphate were practically absent in the water; silicate concentration and $\mathrm{pH}$ ranged $0.3-0.7 \mathrm{mg} \cdot \mathrm{l}^{-1}$ and 7-8, respectively, without any difference among aquaria. Calcium concentration for every aquaria was: 1) 46 , 2) $44-46$, 3) $46-50$ and 4) $50-54 \mathrm{mg} \cdot \mathrm{l}^{-1}$. 


\section{DISCUSSION}

The life cycle of crayfish progresses through a series of moults interspersed by intermoults, during which the animals increase in size. Growth is therefore a function of both length increment per moult and the number of moults completed per unit time. Size increase during moult period results from many factors and, combined with changes in the frequency of moulting, makes the analysis of crayfish growth particularly complex.

Temperature, along with other abiotic factors (LOWERY, 1988), is known to have a large effect on the survival and growth of crayfish in natural environments. In Astacus astacus juveniles we found that temperature had an influence on moulting frequencies only, as already shown in Austropotamobius pallipes (LOWERY, 1988). According to NYSTRÖM (2002), the optimal thermal range for noble crayfish is relatively wide, from 16 to $24{ }^{\circ} \mathrm{C}$ that allows this species to adapt to a broad variety of habitats, from cold rivers to warmer lakes. This may explain the limited thermal dependence in the range $15-22{ }^{\circ} \mathrm{C}$ of juvenile $A$. astacus survival and growth, as revealed by our study.

Oxygen uptake is strictly related to temperature. Losses due to metabolic functions are important components of the energy budget in all the organisms and are usually measured by oxygen consumption. PROSSER (1991) showed that both the activity and metabolism had a logarithmic increase with temperature, following the principle of Arrhenius. A similar trend was found by PAGLIANTI et al. (2004) in A. italicus: juveniles of this species had a higher oxygen uptake rates with the increased temperature $\left(16^{\circ} \mathrm{C}, 20\right.$ ${ }^{\circ} \mathrm{C}$, and $24^{\circ} \mathrm{C}$ ). WHITLEDGE and RABENI (2003) observed a positive relationship between temperature $\left(18^{\circ} \mathrm{C}, 22^{\circ} \mathrm{C}, 26^{\circ} \mathrm{C}\right.$, and $\left.30^{\circ} \mathrm{C}\right)$ and respiration rate of five Orconectes species with a different distribution in Missouri, U.S.A. Our results showed no positive relationship between temperature and respiration rate in contrast with PAGLIANTI et al. (2004) and WHITLEDGE and RABENI (2003), but the occurrence of the noble crayfish in water bodies with different thermal regimes may explain this discrepancy. In fact, several invertebrates do not follow in their metabolism the Arrhenius' logarithmic trend, but their oxygen uptake is maintained at a relatively constant value within the environmental temperature range in which they usually live (NEWELL and NORTHCROFT, 1967; VERNBERG and VERNBERG, 1972; NEWELL, 1976; BÜCKLE et al., 1994; GUTIÉRREZ-YURRITA, 2000). This was also observed by FRY (1957) in some species of freshwater fishes.

Studies carried out on fishes showed that maximum daily consumption is also influenced by temperature: Cmax initially increases with temperature, peaking or reaching a plateau at some intermediate values $\left(\operatorname{Tmax}_{\mathrm{C}}\right)$, and then declines rapidly as temperature approaches the upper thermal tolerance limit for the species (KITCHELL et al., 1977; JOBLING, 1993; ELLIOT, 1994; HAYWARD and ARNOLD, 1996; ZWEIFEL et al., 1999). Consequently, growth scope is maximised at temperature slightly lower than $\operatorname{Tmax}_{C}$, declining precipitously under $\operatorname{Tmax}_{C}$. A raise in the temperature did not exert any influence on the Cmax and growth scope in $A$. astacus reared at $15{ }^{\circ} \mathrm{C}$ and $22{ }^{\circ} \mathrm{C}$ in disagreement with the results of WHITLEDGE and RABENI (2003) to Orconectes genus. As just seen for respiration rates, the wide optimal thermal range of the noble crayfish could be the probably explanation of these differences.

Food availability is another important factor that influences survival and growth in freshwater species. The present study showed a significant increase of juvenile $A$. astacus growth performance with a higher ration size in agreement with the results obtained by others authors (D'AGARO, 2004). CHAKRABORTY et al. (1995) observed that the pattern of energy allocation of the common carp, Cyprinus carpio, varied with ration size. Increasing the ration level up to an optimal level, a larger amount of ingested energy is available to the crayfish for growth. Several studies have clearly shown that the relationship between growth and ingestion is a non linear curve (BRETT and GROVES, 1979). It is also known from other reseach works carried out with lobster and crayfish species that the growth 
and survival performances may be adversely affected if the containers are too small. In our experiment the stoking density was of $125 \mathrm{~m}^{-2}$ with no adverse effects on growth and survival of juvenile crayfish. In agreement with these findings, GYDEMO and WESTIN (1989) showed that the density could be increased to about $100 \mathrm{~m}^{-2}$ if shelters were in excess and D'ABRAMO et al. (1985) to $200 \mathrm{~m}^{-2}$ if proper feed is given.

Values of increments per moults in $A$. astacus (range: 0.54-19.93\%, mean: $10.37 \%$ ), were similar to the values found in A. italicus by PAGLIANTI and GHERARDI (2004) that however contrast with other studies showing higher increments of crayfish species, such as Cherax destructor (VERHOEF et al., 1998) reared in laboratory conditions. Moreover the number of moults was lower than expected, probably due to the physical confinement of crayfish in small compartments (GOYERT and AVAULT, 1978) that however had the advantage to prevent cannibalism and fights and to provide a given amount of food to each crayfish.

Discrepancies between different studies might be explained by the chemical characteristics of the used diet. In fact, a diet with a low level of proteins can reduce moult increments and extend the intermoult period in decapod crustaceans (HARTNOLL, 1982), as found in C. destructor (JONES et al., 1996). Protein requirements of crayfish vary from 20 to $50 \%$ (GODDARD, 1988): C. tenuimanus growth is slow at protein levels below $20 \%$, while at levels above $30 \%$ no significant increase in growth rate was achieved (TSVETNENKO et al., 1995). An optimal diet protein level of $20 \%$ was also reported for Procambarus clarkii (HUNER and MEYERS, 1979). The diet used in our experiment had a rather high value of crude proteins ( $40.95 \%$ DM), even if a diet based on zooplankton may induce better growth than most pelleted diets (MITCHELL and COLLINS, 1989; JONES et al., 1995; AUSTIN et al., 1997; VERHOEF et al., 1998). It is also evident that the availability of different feed sources is more important than the dietary protein level as reported for pond-reared C. tenuimanus (VILLARREAL, 1988). Previous study (D'AGARO et al., 2004) suggested that Elodea canadensis could be used in the aquaculture practice as a cheap supplemental food in order to increase the growth and the survival in summerling noble crayfish.

Besides these factors, in agreement with VERHOEF et al. (1998), we hypothesise that an inherent diversity in the life-cycle strategy between species may be in large part responsible for differences in crayfish growth rate and in metabolic responses. While $r$-selected species, such as $C$. destructor, show rapid growth, early maturity, and a shorter life span (HONAN and MITCHELL, 1995), both $A$. italicus and $A$. astacus display characteristics proper of a K-selected species, as longevity, slow to moderate growth, low fecundity, and low juvenile survival rates (TAMKEVICIENE, 1988; HONAN and MITCHELL, 1995).

\section{REFERENCES}

ABRAHAMSSON S.A.A., 1971. Density, growth, and reproduction in populations of Astacus astacus and Pacifastacus leniusculus in an isolated pond. Oikos, 22, 373-380.

ACKEFORS H., GYDEMO R., KEYSER P., 1995. Growth and moulting in confined juvenile noble crayfish Astacus astacus (L.) (Decapoda, Astacidae). Freshwater Crayfish, 10, 396-409.

ADAMS S.M., BRECK J.E., 1990. Bioenergetics. In: SCHRECK C.B. and MOYLE P.B., (eds.), Methods for fish biology, 389-415, American Fisheries Society, Bethesda, MD.

AOAC, 1990. Official Methods of Analysis, $15^{\text {th }}$ edition. Association of Official Analytical Chemists (AOAC), Washington, D.C. 
AUSTIN C.M., 1995. Effect of temperature and salinity on the survival and growth of juvenile redclaw (Cherax quadricarinatus). Freshwater Crayfish, 10, 419-426.

AUSTIN C., JONES P.F., STAGNITTI F., MITCHELL B.D., 1997. Response of the yabby, Cherax destructor Clark, to natural and artificial diets: phenotypic variation in juvenile growth. Aquaculture, 149, 39-46.

BRETT J.R., GROVES T.D.D., 1979. Physiological energetics. In: HOAR W.S., RANDALL D.J. and BRETT J.R. (eds.), Fish Physiology, Vol. 8, 279-352, New York, Academic Press.

BRINCK P., 1975. Crayfish in Sweden. Freshwater Crayfish, 2, 609-620.

BÜCKLE L.F., DìAZF., CORREA F., BARÓN B., HERNÁNDEZM., 1994. Diel thermoregulation of the crawfish Procambarus clarkii (Crustacea: Cambaridae). Journal of Thermal Biology, 19, 419-422.

CECH J.J., 1990. Respirometry. In: SCHRECK C.B. and MOYLE P.B., (eds.), Methods for fish biology, 335-362, American Fisheries Society, Bethesda, MD.

CHAKRABORTY S.C., ROSS L.G., ROSS B., 1995. Energy budget and metabolism in common carp, Cyprinus carpio L., fed on different dietary protein levels and at different ration levels. Aquaculture Nutrition, 1, 179-187.

COREY S., 1987. Comparative fecundity of four species of crayfish in southwestern Ontario, Canada (Decapoda, Astacidae). Crustaceana, 52, 276-280.

D'ABRAMO L.R,, WRIGHT J.S., WRIGHT K.H., BORDNER C.E., CONKLIN D.E., 1985. Sterol requirement of cultured juvenile crayfish, Pacifastacus leniusculus. Aquaculture, 49, 245-255.

D'AGARO E., 2004. Optimizing growth parameters of noble crayfish Astacus astacus L. reared in water recirculating culture system: effect of dietary fatty acids and feeding level. Freshwater Crayfish, 14, 81-89.

D'AGARO E., RENAI B., GHERARDI F., 2004. Evaluation of the American waterweed (Elodea canadensis Michx.) as supplemental food for the noble crayfish, Astacus astacus. Bull. Fr. Pêche Piscic., 372-373, 439-445.

ELLIOT J.M., 1994. Quantitative ecology of the brown trout. Oxford University Press, New York, $286 \mathrm{p}$.

FRY F.E.J., 1957. The aquatic respiration of fish. In: Brown M.E. (ed.), The physiology of fishes, Vol. 1, 1-63, New York, Academic Press,

GARVEY J.E., STEIN R.A., THOMAS H.M., 1994. Assessing how fish predation and interspecific prey competition influence a crayfish assemblage. Ecology, 75, 532547.

GEDDES M.C., MILLS B.J., WALKER K.F., 1988. Growth in the Australian freshwater crayfish Cherax destructor Clark, under laboratory conditions. Australian Journal of Marine and Freshwater Research, 39, 555-568.

GODDARD J.S., 1988. Food and Feeding. In: HOLDICH D.M. and LOWERY R.S. (eds.), Freshwater Crayfish: Biology, Management and Exploitation, 145-166, London, Croom Helm.

GOYERT J., AVAULT JR. J.W., 1978. Effects of container size on growth of crayfish, (Procambarus clarkii) in a recirculating culture system. Freshwater Crayfish, 4, 277286. 
GUTIÉRREZ-YURRITA P.J., 2000. El Papel Ecológico Del Cangrejo Rojo (Procambarus clarkii), en El Parque Nacional De Doñana. Una Perspectiva Ecofisiológica y Bioenergética. Servicio de Publicaciones, Universidad Autónoma de Madrid, Spain, 280 p.

GYDEMO R., WESTIN L., 1989. Growth and survival of juvenile Astacus atacus L. under optimal water temperature conditions. In:DE PAUN N., JASPERS E., ACKEFORS H., (eds), Aquaculture - A biotechnology in progress, 360-365, European Aquaculture Society, Bredene, Belgium.

HARTNOLL R.G., 1982. Growth. In: Bliss D.E. (ed. in chief), The Biology of Crustacea. Vol. 2, ABELE L.G. (ed.), Embryology, morphology and genetics: the biology of Crustacea, 111-196, New York, Academic Press.

HAYWARD R.S., ARNOLD E., 1996. Temperature dependence of maximum daily consumption in white crappie: implications for fisheries management. Transactions of the American Fisheries Society, 125, 132-138.

HEWETT S.W., JOHNSON B.L., 1992. Fish bioenergetics model 2, University of Wisconsin, Sea Grant Institute, Technical Report WIS-SG-92-250, Madison, WI, 79 p.

HOLDICH D.M., 1993. A global review of astaciculture: Freshwater crayfish farming. Aquatic Living Resources, 6, 307-317.

HOLDICH D.M., LOWERY R.S. (eds.), 1988. Freshwater Crayfish: Biology, Management and Exploitation. London, Chapman and Hall, 498 p.

HONAN J.A., MITCHELL B.D., 1995. Reproduction of Euastacus bispinosus Clark (Decapoda: Parastacidae), and trends in the reproductive biology of freshwater crayfish. Australian Journal of Marine and Freshwater Research, 46, 485-499.

HOPKINS K.D., 1992. Reporting fish growth: a review of the basics. Journal of the World Aquaculture Society, 23, 173-179.

HUNER J.V., MEYERS S.P., 1979. Dietary protein requirements of the red crayfish, Procambarus clarkii, growth in a closed system. Proceedings of the World Mariculture Society, 10, 751-760.

JOBLING M., 1993. Bioenergetics: feed intake and energy partitioning. In: RANKIN J.C. and JENSEN F.B. (eds.), Fish ecophysiology, 1-44, London, Chapman and Hall.

JOBLING M., 1997. Temperature and growth: modulation of growth rate via temperature change. In: WOOD C.M. and MCDONALD D.G. (eds.), Global warming: implications for freshwater and marine fish, 225-253, Cambridge, Cambridge University Press, U.K.

JONES C.M., ROMAIRE R.P., 1995. Effect of temperature on growth and survival of the tropical freshwater crayfish Cherax quadricarinatus (von Martens) (Decapoda: Parastacidae). Freshwater Crayfish, 8, 391-398.

JONES P.L., AUSTIN C.M., MITCHELL B.D., 1995. Growth and survival of juvenile Cherax albidus Clark cultured intensively on natural and formulated diets. Freshwater Crayfish, 10, 480-493.

JONES P.L., DE SILVA S., MITCHELL B.D., 1996. Effect of dietary protein content on growth performance, feed utilisation and carcass composition in the Australian freshwater crayfish, Cherax albidus Clark and Cherax destructor Clark (Decapoda, Parastacidae). Aquaculture Nutrition, 2, 141-150. 
KING C.R., 1994. Growth and survival of redclaw crayfish hatchlings (Cherax quadricarinatus von Martens) in relation to temperature, with comments on the relative suitability of Cherax quadricarinatus and Cherax destructor for culture in Queensland. Aquaculture, 122, 75-80.

KITCHELL J.F., STEWART D.J., WEININGER D., 1977. Applications of a bioenergetics model to yellow perch (Perca flavescens) and walleye (Stizostedion vitreum vitreum). Journal of the Fisheries Research Board of Canada, 34, 1922-1935.

LAMPERT W., 1986. Response of the respiratory rate of Daphnia magna to changing food conditions. Oecologia, 70, 495-501.

LOWERY R.S., 1988. Growth, Moulting, and Reproduction. In: HOLDICH D.M. and LOWERY R.S. (eds.), Freshwater Crayfish: Biology, Management and Exploitation, 83-113, London, Chapman and Hall.

MILLS B.J., 1989. Australian freshwater crayfish handbook of aquaculture. Freshwater Crayfish Aquaculture Research and Management. Lymington, Tasmania, Australia. $116 \mathrm{p}$.

MITCHELL B.D., COLLINS R.O., 1989. Development of field-scale intensive culture techniques for the commercial production of the yabbie (Cherax destructor/albidus). Completion Report for Project CAE/8660, Rural Credits Development Fund, Centre for Aquatic Science, 89-100, Warrnambool Institute of Advanced Education, Warrnambool, Australia.

MOMOT W.T., 1984. Crayfish production: a reflection of community energetics. Journal of Crustacean Biology, 4, 35-54.

MOMOT W.T., 1995. Redefining the role of crayfish in aquatic ecosystems. Reviews in Fisheries Science, 3(1), 33-63.

MORRISSY N.M., 1990. Optimum and favourable temperatures for growth of Cherax tenuimanus (Smith, 1912) (Decapoda: Parastacidae). Australian Journal of Marine and Freshwater Research, 41, 735-746.

MUCK J.A., 1995. Life history of three crayfish from the Ozark National Scenic Riverway: Orconectes luteus, O. ozarkae and Orconectes punctimanus. M.Sc. Thesis, University of Missouri-Columbia, $247 \mathrm{p}$.

MUNDAHL N.D., BENTON M.J., 1990. Aspects of the thermal ecology of the rusty crayfish Orconectes rusticus (Girard). Oecologia, 82, 210-216.

NEWELL R.C., 1976. Adaptations to Environment: Essays on the Physiology of Marine Animals. Butterworths, London, $539 \mathrm{p}$.

NEWELL R.C., NORTHCROFT H.R., 1967. A reinterpretation of the effect of temperature on the metabolism of certain marine invertebrates. Journal of Zoology (London), 151, 277-298.

NYSTRÖM P., 2002. Ecology. In: HOLDICH D.A. (ed.), Biology of freshwater crayfish, 192235, Blackwell Science, Oxford.

PAGLIANTI A., GHERARDI F., 2004. Combined effects of temperature and diet on growth and survival of young-of-year crayfish: a comparison between indigenous and invasive species. Journal of Crustacean Biology, 24(1), 140-148.

PAGLIANTI A., MESSANA G., GHERARDI F., 2004. Oxygen consumption At different temperatures In YOY Crayfish: A Comparison Between Indigenous and Invasive Species. Freshwater Crayfish, 14, 1-6. 
PROBST W.E., RABENI C.F., COVINGTON W.G., MARTENEY R.E., 1984. Resource use by stream-dwelling rock bass and smallmouth bass. Transactions of the American Fisheries Society, 113, 283-294.

PROSSER C.L. (ed.), 1991. Comparative animal physiology: Environmental and metabolic animal physiology. New York, (ed.) Wiley-Liss.

RABENI C.F., 1985. Resource partitioning by stream-dwelling crayfish: the influence of body size. American Midland Naturalist, 113, 20-29.

ROUSE D.B., KARTAMULIA I., 1992. Influences of salinity and temperature on moulting and survival of the Australian freshwater crayfish Cherax tenuimanus. Aquaculture, $105,47-52$.

RUDSTAM L.G., 1989. A bioenergetic model for Mysis growth and consumption applied to a Baltic population of Mysis mixta. Journal of Plankton Research, 11, 971-978.

SMALLRIDGE M., GEDDES M.C., 1991. Juvenile yabbies growth at artificially elevated temperatures. Safish (South Australian Department of Fisheries), 16, 15-16.

SPITZY R., 1973. Crayfish in Austria, history and actual situation. Freshwater Crayfish, 1, 10-14.

TAMKEVICIENE E.A., 1988. Growth and development of juveniles of the native and introduced species of freshwater crayfish. Freshwater Crayfish, 7, 396-400.

TAYLOR C.A., WARREN JR. M.L., FITZPATRICK JR. J.F., HOBBS III H.H., JEZERINAC R.F., PFLIEGER W.L., ROBINSON H.W., 1996. Conservation status of crayfishes of the United States and Canada. Fisheries, 21, 25-40.

TSVETNENKO Y., SANTELICES M., EVANS L.H., 1995. Effect of dietary protein levels and beta-carotene on growth of marron Cherax tenuimanus in an intensive culture system. Freshwater Crayfish, 10, 611-622.

VERHOEF G.D., AUSTIN C.M., JONES P.L., STAGNITTI F., 1998. Effect of temperature on molt increment and intermolt period of a juvenile Australian fresh-water, Cherax destructor. Journal of Crustacean Biology, 18(4), 673-679.

VERNBERG W.B., VERNBERG F.J., 1972. Environmental physiology of marine animals. Springer-Verlag, Berlin, Heidelberg and New York, 346 p.

VILLARREAL H., 1988. Culture of the Australian freshwater crayfish Cherax tenuimanus (Marron) in Eastern Australia. Freshwater Crayfish, 7, 401-408.

VILLARREAL H., 1991. A partial energy budget for the Australian crayfish Cherax tenuimanus. Journal of the World Aquaculture Society, 22(4), 252-259.

WARREN C.E., DAVIS G.E., 1967. Laboratory studies on the feeding, bioenergetics, and growth of fishes. In: GERKING S.B. (ed.), The biological basis of freshwater fish production, 175-214, Wiley, New York.

WESTMAN K., 1973. Cultivation of the American crayfish Pacifastacus leniusculus. Freshwater Crayfish, 3, 211-220.

WESTMAN K., PURSIAINEN M., WESTMAN P., 1990. Status of crayfish stocks, fisheries, disease and culture in Europe. Report of the FAO European Inland Fisheries Advisory Commission (EIFAC) Working Party on Crayfish, 206 p.

WETZEL II J.E., BROWN P.B., 1993. Growth and survival of juvenile Orconectes virilis and Orconectes immunis at different temperatures. Journal of the World Aquaculture Society, 24, 339-343. 
WHITLEDGE G.W., RABENI C.F., 2003. Maximum daily consumption and respiration rates at four temperatures for five species of crayfish from Missouri, U.S.A. (Decapoda, Orconectes spp.). Crustaceana, 75(9), 1119-1132.

ZAR J.H., 1990. Biostatistical analysis. Prentice-Hall, Inc., Englewood Cliffs, New Jersey, $620 \mathrm{p}$.

ZWEIFEL R.D., HAYWARD R.S., RABENI C.F., 1999. Bioenergetics insight into black bass distribution shifts in Ozark border region streams. North American Journal of Fisheries Management, 19, 192-197. 